\title{
Determinants of Child Labour and Schooling in Botswana: Evidence from 2005/2006 Labour Force Survey
}

\author{
Okurut, F.N. \& D.O. Yinusa ${ }^{1}$
}

\begin{abstract}
The rise in child labour and the negative effect of it on child schooling outcomes is an important policy issue in developing countries. However, despite almost universal agreement that child labour is undesirable, there is wide disagreement on how to tackle the problem. The formulation of policies that are effective in curbing child labour requires a clear understanding of the key determinants of child employment. This article contributes to the debate by providing an analysis of the key determinants of child labour and schooling in an upper middle-income country, Botswana. The study used the Labour Force Survey (LFS) 2005/06 data from the Central Statistics Office (CSO) and the multinomial logit model for analytical work. The results suggest that the probability of children working while schooling is negatively and significantly influenced by the age of the child, being from a female headed household and employment status of the household head. However the probability of child labour and schooling is positively and significantly influenced by child education level, the number of children in the household, and the household head being engaged mainly in the agricultural sector.
\end{abstract}

Key Words: Child Labour, Multinomial Logit Model, Botswana, JEL: J2, C25, C3

\section{Introduction}

The literature is replete with studies on child labour. The growing interest of economists in child labour stems from the rise in child labour in developing countries which was perceived to have negative consequences on school enrolments and educational outcomes with serious effects on child health, human capital development and welfare. Therefore, child labour has become one of the most important policy issues in the agenda of most countries. More importantly, the demographic and socioeconomic factors causing a child to be engaged in the labour market vary across countries and continents. For example, the evidence presented in Ray (2000a) shows that the nature of child labour, its key determinants and, consequently, the strategies at reducing it, vary between countries. Bonnet (1993) argues that in the African context the poor quality of child schooling and their lack of apparent relevance to

1. Both authors are based in the Department of Economics, University of Botswana. Emails: okurutf@mopipi.ub.bw and yinusado@mopipi.ub.bw 
the child's employment skills encourage parents to take their children out of schools and put them into employment.

However, despite almost universal agreement that child labour is undesirable, there is wide disagreement on how to tackle the problem. Therefore, the formulation of policies that are effective in curbing child labour requires an analysis of its key determinants as this study intends to do. It is important to study determinants of child labour because: child labour encourages children to drop out of school; it undermines human capital development and future earnings; reinforces the vicious cycle of poverty, and runs counter to Botswana Vision 2016 of being "An educated nation". The Botswana Employment Act stipulates that no child less than 15 years shall be employed in any capacity whatsoever. But, a child aged 14 years and not attending school may be employed on light work not harmful to his/her health or development (CSO, 2007).

On the policy side, it will be necessary to understand individual and household characteristics of children involved in child labour. What sectors are the children mainly involved in child labour? Are the children concurrently working as well as schooling? What factors motivate children to engage in labour markets given the free universal education in Botswana? What policy measures should be put in place to address the problem of child labour as a strategy for poverty alleviation? What does the Labour Force Survey data 2005/06 tell us about child labour in Botswana? These issues are investigated in this study using descriptive statistics and a multinomial logit model.

\section{Employment Status of Children in Botswana}

The analysis focussed on children of school going age (aged between 7 and 17) using weighted data with approximately 415,751 children. The children were decomposed into four employment and schooling states: 1 = working and schooling; $2=$ working and not schooling; 3 = not working and schooling; 4 = not working and not schooling. Of the 415,751 children captured in 2005/06 LFS, 72.4 percent were involved in schooling only, 21.2 percent were involved in labour market activities as well as schooling, 2.6 percent were involved in working only, while 4 percent were not working and not schooling. Given Botswana's vision 2016 of getting an educated and well informed population, the ideal scenario would be for all children to be in school without engagement in labour market activities given the free education policy and the welfare grants system for the poor households. This therefore motivated the analysis of the socio-economic characteristics of the chilldren in the various employment and schooling states with a view of getting a better understanding of the factors that influence child employment and schooling behaviour. In effect policy concerns are on the approximately 28 percent of all the children in the three employment and schooling states (i.e. working and schooling; working and not schooling; not working and not schooling). 
Table 1: Child Employment and Schooling Status

\begin{tabular}{|l|c|c|}
\hline Child employment and schooling status & Frequency & Percent \\
\hline Working and schooling & 88,120 & 21.2 \\
\hline Working and not schooling & 10,877 & 2.6 \\
\hline Not working and schooling & 300,135 & 72.4 \\
\hline Not working and not schooling & 16,620 & 4.0 \\
\hline Total & 415,751 & 100.2 \\
\hline
\end{tabular}

Source: Authors' calculations based on CSO Labour Force Survey (2005/06)

Of the 415,751 children, 59 percent were from female headed households, while 41 percent were from male headed households. Within the children from male headed households, 69.4 percent were involved in schooling only, 22.9 percent were working and schooling, 3.2 percent were working and not schooling, and 4.5 percent were not working and not schooling. Within the female headed households, 74.1 percent of the children were engaged in schooling only, 20 percent were schooling and working, 2.2 percent were working and not schooling, and 3.6 percent were not working and not schooling. The results suggest that the children from female headed households are more likely to be engaged in schooling only as compared to children from male headed households. By implication children from male headed households have a higher probability of engagement in labour market activities.

Table 2: Child Employment and Schooling Status by Gender of Household Head

\begin{tabular}{|c|c|c|c|}
\hline \multirow[b]{2}{*}{$\begin{array}{l}\text { Child employment and schooling } \\
\text { status }\end{array}$} & \multicolumn{2}{|c|}{ Gender of Household Head } & \multirow[b]{2}{*}{$\begin{array}{c}\text { Total } \\
(\mathrm{N}=415,751)\end{array}$} \\
\hline & $\begin{array}{c}\text { Male } \\
(\mathrm{N}=168,764)\end{array}$ & $\begin{array}{c}\text { Female } \\
(\mathrm{N}=246,987)\end{array}$ & \\
\hline Working and schooling & 22.9 & 20.0 & 21.2 \\
\hline Working and not schooling & 3.2 & 2.2 & 2.6 \\
\hline Not working and schooling & 69.4 & 74.1 & 72.0 \\
\hline Not working and not schooling & 4.5 & 3.6 & 4.0 \\
\hline Total & 100.0 & 100.0 & 100.0 \\
\hline
\end{tabular}

Source: Authors' calculations based on CSO Labour Force Survey (2005/06)

The orphan status of the children was generated as a categorical variable: $1=$ both parents alive; $2=$ only one parent alive; $3=$ both parents dead. Of the 415,043 children on whom the parents' living status was given, 69 percent had both parents alive, 25 percent had only one parent alive; and 6 percent were complete orphans. The orphaned children were least likely to be engaged in full time schooling (63.6 percent) as compared to children with single parents (71.3 percent) and children with both parents alive (73.3 percent). By contrast orphaned children are more likely to 
be working and schooling (25.3 percent) as compared to children with both parents alive ( 20.6 percent) or children with a single parent alive ( 22 percent). The orphaned children were also more likely to be working and not schooling, not working and not schooling as compared to children with either both or one parent alive. It can be concluded that orphan hood increases the likelihood of children being engaged in labour market activities. But given the fact that social welfare grants are provided by the state to orphans to enable them to cope and continue to be in school, this may imply that the social welfare grants for the orphans do not reach the intended beneficiaries. This calls for the streamlining of the social welfare grants system to ensure that the orphans as the intended beneficiaries receive them.

Table 3: Child Employment and Schooling Status by Child

\section{Orphan Status}

\begin{tabular}{|l|c|c|c|c|}
\hline $\begin{array}{l}\text { Child employment and } \\
\text { schooling status }\end{array}$ & $\begin{array}{c}\text { Both Parents } \\
\text { Alive } \\
(\mathrm{N}=284,647)\end{array}$ & $\begin{array}{c}\text { Single Parent } \\
(\mathrm{N}=104,901)\end{array}$ & $\begin{array}{c}\text { Orphan } \\
(\mathrm{N}=25,495)\end{array}$ & $\begin{array}{c}\text { Total } \\
(\mathrm{N}=415,043)\end{array}$ \\
\hline Working and schooling & 20.6 & 22.0 & 25.3 & 21.2 \\
\hline $\begin{array}{l}\text { Working and not } \\
\text { schooling }\end{array}$ & 2.4 & 2.7 & 4.6 & 2.6 \\
\hline $\begin{array}{l}\text { Not working and } \\
\text { schooling }\end{array}$ & 73.3 & 71.3 & 63.6 & 72.0 \\
\hline $\begin{array}{l}\text { Not working and not } \\
\text { schooling }\end{array}$ & 3.7 & 4.1 & 6.5 & 4.0 \\
\hline Total & 100.0 & 100.0 & 100.0 & 100.0 \\
\hline
\end{tabular}

Source: Authors' calculations based on CSO Labour Force Survey (2005/06)

There were an approximate equal proportion of female and male children captured by the survey. The female children were more likely to be engaged in schooling only (75.1 percent) as compared to male children (69.2 percent), which may partly be explained by the traditional practices of engaging children in cattle posts. The male children were more likely to be working and schooling (24.1 percent) as compared to female children (18.3 percent).

Table 4: Child Employment and Schooling Status by Gender of Child

\begin{tabular}{|l|c|c|c|}
\hline \multirow{2}{*}{$\begin{array}{l}\text { Child employment and } \\
\text { schooling status }\end{array}$} & \multicolumn{2}{|c|}{ Gender of Child } & \multirow{2}{*}{$\begin{array}{c}\text { Total } \\
(\mathrm{N}=415,751)\end{array}$} \\
\cline { 2 - 3 } & $\begin{array}{c}\text { Male } \\
(\mathrm{N}=207,713)\end{array}$ & $\begin{array}{c}\text { Female } \\
(208,038)\end{array}$ & 21.2 \\
\hline Working and schooling & 24.1 & 18.3 & 2.6 \\
\hline Working and not schooling & 3.5 & 1.8 & 72.0 \\
\hline Not working and schooling & 69.2 & 75.1 & 4.0 \\
\hline Not working and not schooling & 3.2 & 4.8 & 100.0 \\
\hline Total & 100.0 & 100.0 & \\
\hline
\end{tabular}

Source: Authors' calculations based on CSO Labour Force Survey (2005/06) 
Of the 70,819 children for which the specific sector in which they were employed was specified, 67.6 percent were working on own family lands/cattle post/farm, 12.4 percent were engaged in unpaid work in a family business, 9 percent were engaged in self employment, and 6.5 percent were employed by private households. The gender analysis of the children by the sector of employment suggests that male children are more likely to be engaged in working on family land/cattle posts/farms (71.6 percent) as compared to female children (61.6 percent). However female children are more likely to be engaged in private sector employment, unpaid work in a family business, and employment in private households than male children.

Table 5: Sector of Employment by Gender of Children

\begin{tabular}{|l|c|c|c|}
\hline \multirow{2}{*}{ Sector } & \multicolumn{2}{|c|}{ Gender of Children } & $\begin{array}{c}\text { Total } \\
(\mathrm{N}=70,819)\end{array}$ \\
\cline { 2 - 4 } & $\begin{array}{c}\text { Male } \\
(\mathrm{N}=42,050)\end{array}$ & \multicolumn{2}{c|}{ Female (N=28,769) } \\
\hline $\begin{array}{l}\text { Working on own family lands/ } \\
\text { cattle post or farm }\end{array}$ & 71.6 & 61.6 & 67.6 \\
\hline Central government & 0.1 & 0.3 & 0.2 \\
\hline Local government & 0.3 & 0.8 & 0.5 \\
\hline Parastatal & 0.1 & 0.0 & 0.1 \\
\hline Private sector & 2.7 & 4.3 & 3.3 \\
\hline Non-government organization & 0.0 & 0.1 & 0.1 \\
\hline Private household & 6.3 & 6.8 & 6.5 \\
\hline Business with employees & 0.4 & 0.4 & 0.4 \\
\hline Business without employees & 8.3 & 10.0 & 9.0 \\
\hline $\begin{array}{l}\text { Unpaid work in a family } \\
\text { business }\end{array}$ & 10.2 & 15.6 & 12.4 \\
\hline Total & 100.0 & 100.0 & 100.0 \\
\hline
\end{tabular}

Source: Authors' calculations based on CSO Labour Force Survey (2005/06)

The children are engaged in labour market activities mainly in form of seasonal employment (39.5 percent), followed by temporary employment (28.7 percent), casual employment (15.5 percent) and permanent employment (10 percent).

Table 6: Term of Employment by Gender of Children

\begin{tabular}{|l|c|c|c|}
\hline \multirow{2}{*}{ Term of Employment } & \multicolumn{2}{|c|}{ Gender of Children } & \multicolumn{1}{c|}{$\begin{array}{c}\text { Total } \\
(\mathrm{N}=70,753)\end{array}$} \\
\cline { 2 - 4 } & $\begin{array}{c}\text { Male } \\
(\mathrm{N}=42,050)\end{array}$ & \multicolumn{2}{|c|}{ Female $(\mathrm{N}=28,703)$} \\
\hline Permanent & 11.1 & 8.5 & 10.0 \\
\hline A fixed period contract & 0.4 & 0.7 & 0.5 \\
\hline Casual & 17.7 & 12.3 & 15.5 \\
\hline
\end{tabular}




\begin{tabular}{|l|c|c|c|}
\hline Seasonal & 34.3 & 47.1 & 39.5 \\
\hline Temporary & 30.4 & 26.1 & 28.7 \\
\hline Don't know & 5.9 & 5.3 & 5.6 \\
\hline Other & 0.2 & 0.0 & 0.1 \\
\hline Total & 100.0 & 100.0 & 100.0 \\
\hline
\end{tabular}

Source: Authors' calculations based on CSO Labour Force Survey (2005/06)

Only 39,170 children stated the main reason for their engagement in labour market activities. The three main reasons for children to engage in labour market activities include duty to help family (62.8 percent), to obtain money for own use (12.8 percent), and to assist the family with money (11.9 percent). The gender decomposition suggests that female children are more likely to engage in labour market activities to obtain money to assist the family and also money for personal use as compared to male children. However the male children are more likely to engage in labour market activities as a duty to help the family with farming activities as compared to female children.

Table 7: Main Reasons Children Working

\begin{tabular}{|l|c|c|c|}
\hline \multirow{2}{*}{ Reason } & \multicolumn{2}{|c|}{ Gender of Children } & \multicolumn{1}{c|}{$\begin{array}{c}\text { Total } \\
(\mathrm{N}=39,170)\end{array}$} \\
\cline { 2 - 4 } & $\begin{array}{c}\text { Male } \\
\mathrm{N}=29,972)\end{array}$ & \multicolumn{2}{c|}{ Female $(15,198)$} \\
\hline Assist family with money & 10.1 & 14.6 & 11.9 \\
\hline To obtain money for own use & 12.1 & 14.0 & 12.8 \\
\hline $\begin{array}{l}\text { Duty to help family e.g. with } \\
\text { farming }\end{array}$ & 67.0 & 56.1 & 62.8 \\
\hline Obligation to landlord & 0.2 & 0.0 & 0.1 \\
\hline $\begin{array}{l}\text { Finished school and no other } \\
\text { activity available }\end{array}$ & 0.7 & 1.7 & 1.1 \\
\hline $\begin{array}{l}\text { School class not operating/ } \\
\text { teacher missing }\end{array}$ & 1.4 & 2.9 & 2.0 \\
\hline To gain experience/training & 1.6 & 0.0 & 1.0 \\
\hline Other & 0.2 & 0.4 & 0.2 \\
\hline Not stated & 6.8 & 10.3 & 8.1 \\
\hline Total & 100.0 & 100.0 & 100.0 \\
\hline
\end{tabular}

Source: Authors' calculations based on CSO Labour Force Survey (2005/06)

Almost 79.4 percent of all the children engaged in labour market activities are not given any cash earnings, which is indicative of high unpaid labour among the children. Approximately 6.7 percent of the children have part of their earnings from labour market activities paid to parents/adults in the family. This scenario may arise where the child is employed for example by a private household as a housemaid 
and the money paid directly to parents/adults in the family, which is indicative of the exploitation of children. Only 13.5 percent of the children receive their earnings from labour market activities themselves. The gender decomposition suggests that both female and male children are equally likely to have part of their earnings paid to parents/adults in the family. The male children are also more likely not to receive cash earning for their labour (80.4 percent) as compared to female children (77.9 percent).

Table 8: Earnings from Child Labour Paid to Parent/Adults in Family

\begin{tabular}{|l|c|c|c|}
\hline \multirow{2}{*}{\begin{tabular}{l} 
Earnings Paid to Parents/ \\
\cline { 2 - 4 }
\end{tabular}} & \multicolumn{2}{|c|}{$\begin{array}{c}\text { Gender of Children } \\
\text { Male } \\
(\mathrm{N}=21,718)\end{array}$} & \multicolumn{2}{|c|}{ Female $(\mathrm{N}=13,559)$} \\
\hline Yes, all or almost all & 2.2 & 2.1 & 2.2 \\
\hline Yes, half or more & 2.1 & 2.7 & 2.3 \\
\hline Yes, less than half & 2.2 & 2.2 & 2.2 \\
\hline No & 13.1 & 14.2 & 13.5 \\
\hline No cash earnings & 80.4 & 77.9 & 79.4 \\
\hline Other & 0.0 & 0.9 & 0.4 \\
\hline Total & 100.0 & 100.0 & 100.0 \\
\hline
\end{tabular}

Source: Authors' calculations based on CSO Labour Force Survey (2005/06)

While approximately 71.8 percent of the children who are schooling engage in labour market activities on weekends/holidays which may be argued to be good for the development of children into responsible citizens, concern is on the rest of the children who engage in labour market activities daily (or sometimes) before or after school. By implication such children will not have time to concentrate on their studies which will have negative effects on their school performance and human capital development, thereby having adverse effects on their future earnings potential. The gender decomposition of the children by the time they engage in labour market activities suggests that the females are more likely to engage daily (or sometimes) before and after school as compared to male children. The male children are however more likely to be engaged in labour market activities on weekends/holidays than the female children. The burden of daily labour market activities therefore falls more disproportionately on female children.

Table 9: Time when Children who are Schooling and Working Engage in Labor Market Activities

\begin{tabular}{|l|c|c|c|}
\hline $\begin{array}{l}\text { Time of Engagement in } \\
\text { Labour Market }\end{array}$ & $\begin{array}{c}\text { Male } \\
(\mathrm{N}=18,073)\end{array}$ & $\begin{array}{c}\text { Female } \\
(\mathrm{N}=11,939)\end{array}$ & Total (N=30,012) \\
\hline $\begin{array}{l}\text { Daily before school/ } \\
\text { college }\end{array}$ & 1.5 & 4.4 & 2.7 \\
\hline
\end{tabular}




\begin{tabular}{|l|c|c|c|}
\hline Daily after school/college & 15.8 & 18.1 & 16.7 \\
\hline $\begin{array}{l}\text { Daily both before/after } \\
\text { school/college }\end{array}$ & 2.3 & 3.4 & 2.7 \\
\hline Weekends/holidays & 74.9 & 67.0 & 71.8 \\
\hline During school time & 1.1 & 0.0 & 0.6 \\
\hline $\begin{array}{l}\text { Sometimes before/after } \\
\text { school/college }\end{array}$ & 2.5 & 4.2 & 3.2 \\
\hline $\begin{array}{l}\text { Sometimes both before/ } \\
\text { after school/college }\end{array}$ & 1.9 & 2.9 & 2.3 \\
\hline Total & 100.0 & 100.0 & 100.0 \\
\hline
\end{tabular}

Source: Authors' calculations based on CSO Labour Force Survey (2005/06)

\section{Literature Review on Child Labour and Schooling}

Studies on the issue of child labour in developing countries have taken two main dimensions in the literature: those that examine the determinants of work and those that investigate the consequences of work. The first line of research has led to the series of both theoretical and empirical research modelling the determinants of child labour (Brown, Deardorff and Stern, 2002) while the later has dominated much of the policy debate about stopping child labour (ILO, 2006). Yet distinguishing between competing theories of the determinants of child labour with empirical studies has been very challenging. Although, there seem to be some emerging consensus at the empirical level that lack of access to utilities, return to schooling, school cost, cultural traditions and local institutions, the family marginal utility of income, level of education of household head, gender of household head and credit market failure are key determinants of child labour in developing countries, yet, these determinants of child labour and many more tend to vary across countries and across regions (Austen, 2005).

For example, Bonnet (1993) argues in the African context that poor quality of child schooling and their lack of apparent relevance to the child's employment skills encourage parents to take their children out of schools and put them into employment. The evidence presented in Ray (2000) shows that the nature of child labour, its key determinants and, consequently, the strategies at reducing it, vary between countries. Child labour takes different form in different regions. Also, Bhalotra and Heady (2001) investigated the determinants of child labour in rural household from Ghana and Pakistan and concluded that, in addition to the number of siblings, factors such as age, mother's education, region, ethnic, religion, availability of public transports and electricity are variables that show some importance to define the number of hours that children work.

Bock (2002) investigated school attendance and child labour among the 
Okavango Delta Peoples of Botswana. The study used predictions regarding parental investment in the embodied capital of offspring generated by evolutionary theory to examine the pattern of children's time allocation to labour and schooling. Models incorporating individual costs and benefits of resource allocation, conflicts of interests between men and women and between parents and offspring, and the effects of family composition, subsistence ecology, and gender were developed and applied to data on time allocation, household demography, and household economy. The main findings from the study are: (1) The availability of alternative productive tasks strongly affects intra- and intergenerational labour substitution. (2) The presence of similarly aged children of the same sex within the household decreases the likelihood of both boys and girls engaging in a specific productive activity and increases the likelihood of children's school attendance. (3) Birth order, the labour needs of the household, and parents' marital status all affect school attendance.

UNICEF (2007) investigated the determinants of child labour and school enrollment using data from 175 countries. The research questions were designed around three main issues: which factors influence family's decision to subject the child to work? Which factors contribute significantly to child not attending school as a result of its occupation? And what policy options are available for Governments to intervene in this issue? It was argued that poverty, inequality, access to education, culture, parents' education, vulnerability, economic crises, resultant market-oriented adjustment and transition policies tend to exacerbate inequality, often increasing the supply of and demand for children's labour. At the same time, trade liberalization and the increasing internalization of production have created new markets for unskilled, cheap labour, often including that of children. "Economic inequalities, and unregulated rapid growth of market economies, have contributed to child labour by increasing the vulnerability of poor households on the one hand and reducing the resources available for state educational and welfare provision on the other." (UNICEF, 2007:5). In such contexts, sometimes children's work makes a critical contribution to household income and food security, and may thus become more attractive an option for children and parents than under-funded, low quality education (de Carvalho Filho, 2008).

Zylberstajn, Pagotto and Pastore (1985) conducted a study in Brazil to show factors that drive children, teenagers, and women into the labour market. The authors found that the poorest families use the work of children and teenagers in order to survive, mainly because of three reasons: father's handicap, age and health of the son. When they did this study, there were "...27\% of families where the head of the household did not work due to sickness or job accident, living in total or partial handicapped conditions. In this group of families, there are $37 \%$ whose income is exclusively formed by the precarious work of minors." In this case, the option of these children was not between working or not, but between living or starving. Despite this "surviving question", usually others factors are indicated as responsible for childr labour: the unemployment of members in the household, the rupture of 
the family core, with the woman becoming head in the absence of the man, and the invalidity of the household head.

Grootaert (1998) examined the determinants of child labour in Côte d'Ivoire using a sequential probit model. The author identified five key factors which affect the household's decision to supply child labour: the age and the gender of the child, the education and employment status of the parents, the availability of within-household employment opportunities, the household's poverty status and its geographic location. Similarly, it was found that Parent's characteristics, especially education, matter the most at the decision stages involving schooling options. Parents with no or low education are more likely to choose work options for their children. This effect was found to be most pronounced in rural areas and for younger children, and underlines lack of schooling and child labour. The paper concluded by offering a number of policy measures to address the problem of child labour in Côte d'Ivoire

Chaudhri, Nagar, Rahman and Wilson (1999) conducted a preliminary search for the factors which affect demand and supply of child labour in India using OLS technique to estimate both cross sectional and time series data between 1961 and 1991. It was found that child labour is strongly associated with the incidence of poverty, female participation in labour force, and Non-participation in the school system. Kambhampati and Rajan (2004) study the determinants of child work and schooling in rural India using a bivariate probit analysis. They conclude that mother's education, rather than employment or wages, is the single most important factor in reducing a child's work likelihood. Using data on urban Turkey, Dayioglu and Assad (2002) also support this finding.

Khanam (2004) analysed the incidence and determinants of child labour and school attendance in Bangladesh using a multinomial logit model which allows a joint estimation of the determinants of schooling and working, combining schooling and work, or doing nothing for 5-17 year old children. The empirical findings from the article provide evidence that the education of parents significantly increases the probability that a school-age child will specialise in study. It was also showed that children whose fathers are employed in a vulnerable occupation are more likely to work full time or combine work with schooling. Most of the literature on child labour in developing countries finds that boys are more likely to combine study and work. However, Khanam (2004) suggests that girls are more likely than boys to combine schooling with work in Bangladesh.

Although Barros, Mendonça and Velazco (1994) concluded that poverty is not responsible for the entry of children into the Brazilian labour market, Barros and Santos (1991) found that the participation rate of children in the Brazilian labour market is directly and strongly related with the household poverty level. If poverty was the main cause of child labour, then a larger participation rate should be expected in areas and periods of bigger poverty. Several demographic and economic features of the household as a unit affect the supply of child labour. On the demographic 
side, household size and composition are of foremost importance. Ceteris paribus, the more children there are in the household, the more likely it is that one of them will work. The literature has clearly established that larger household size reduces children's educational participation and reduces parental investment in schooling (Lloyd, 1994). A larger household size decreases income per capita and increases the dependency ratio, and both factors increase the likelihood that a child will need to generate income as opportunity cost of school attendance.

Recently, Leme and Wajnman (2000) studied the link between school and work and confirmed that in the decision of just studying, the most important variables are parents' education and household income, followed by the number of kids in the family and the child's gender. Grootaert and Kanbur (1995) discussed the role of fertility behavior, the household's risk management, and government policies with respect to social expenditure and population control as variables which affect the supply of child labour. On the demand side, the structure of the labour market and the prevailing production technology are the two main determinants of child labour. To these economic variables must be added the legislative framework (nationally and internationally), which usually involves a ban on child labour that is rarely enforced effectively, and social factors such as advocacy, awareness raising and communitybased efforts to help child workers and street children. As a final factor, war and civic strife often draw children into militia.

From the above, it is clear that a number of empirical studies of child labour have been conducted in recent years. However, as Basu (1999) points out, there remains considerable scope for good empirical work in this field. At this stage, patterns are only just beginning to emerge among the variety of results in the literature, corresponding to the vast variety of regions, types of child work, and empirical specifications. Indeed, existing beliefs about the causes and consequences of child labour have tended to be shaped by case studies. These typically interview working children with the attendant problem of selection bias. A feasible solution to this problem is the use of large scale representative household surveys as is done in this study. An advantage of using large scale representative household surveys is that we have comparable information for children who work and those who do not work.

Another departure of this study from its predecessors lies in the use of a multinomial logit estimation strategy that simultaneously analyses child employment and child schooling. Nearly all the previous attempts (see, for example, Patrinos and Psacharopoulos (1997), Psacharapoulos (1997), Jensen and Nielsen (1997), Ray (2000)) have used a single equation based standard binomial logit model to analyse child labour and child schooling participation. The binomial logit estimation strategy recognizes only two possibilities in a single estimation, namely, in case of child labour, the child either works or does not and, in case of schooling, either the child attends schooling or does not. In reality, however, there are simultaneously 
four possibilities to choose from: child (a) works and attends school, (b) works but does not attend school, (c) attends school but does not work, and (d) neither works nor attends school. While in Botswana a sizeable proportion of children are in category (a), a large number of children are frequently found in other categories. The multinomial logit estimation strategy adopted in this study, besides incorporating the simultaneity of decisions on child employment and child schooling, recognises these four mutually exclusive and exhaustive possibilities in identifying the key determinants of child labour.

\section{Methodology of the Study}

\subsection{Model specification}

The first major step to understanding the child labour market in Botswana concerns the factors influencing an individual's employment and schooling choice. We endeavour to give insights into the factors influencing the selection into any of the four child employment and schooling states. The child employment and schooling states include child working and schooling; child working and not schooling; child not working and schooling; child not working and not schooling.

We assume individuals are allocated by some data generating process into 4 mutually exclusive employment and schooling states. The equation for the underlying latent variable is given as in Eq. (1).

$$
P_{i s}^{*}=Z^{\prime} \beta_{i}+\varepsilon_{i s}
$$

where $P_{i s}^{*}$ is a latent variable representing the $i^{\text {th }}$ individual utility gain from choosing the $s^{\text {th }}$ employment and schooling choice ( $\mathrm{s}=$ child working and schooling; child working and not schooling; child not working and schooling; child not working and not schooling, indexed $s=1,2,3,4)$. The error term is assumed to be normally distributed with mean zero and unity variance. The $\mathrm{Z}$ vector contains exogenous factors including individual characteristics such as age, sex, education; household characteristics such as gender of the household head, education of household head, household size, and employment status of household head. The individual chooses an employment and schooling state for which utility is highest.

$$
P(s / Z)_{t}=\frac{\exp \left(Z_{i t}^{\prime} \beta_{s t}\right)}{\sum_{s=1}^{s=4} \exp \left(Z_{i t}^{\prime} \beta_{s t}\right)}
$$

The probability of choosing the $s^{\text {th }}$ employment state conditional of $\mathrm{Z}$ vector takes the multinomial logit form as expressed in Equation (2). For identification, $\beta_{0 t}$ are normalised to zero, that is, we make not working the base employment state. 


\subsection{Description of the model variables}

Individual demographic characteristics: These include age, sex, education, orphan status and citizenship. Information on education is collected on the highest grade attained at the time of the survey. This variable was converted into years of schooling. Sex of the children is included in the model in dummy form with male as the base category. The survey collected data on employment for persons aged 7 years and above and as per the Botswana constitution a child is any person below the age of 18. For this study child employment was defined as those aged between 7 and 17 completed years. The orphan status was created as a categorical variable $(1=$ both parents alive; 2 = one parent alive; 3 = all parents dead). Separate dummies were created for each of the categories, with both parents dead being the reference category.

Household characteristics: The household characteristics include education level of household head, gender of household head, employment status of the household head, and household size. The education level of the household head was entered as dummy variables for each of the categories (no formal education, primary education, junior community secondary education, secondary education, and tertiary education). The last category included all those individuals who have gone beyond secondary level education including university graduates and above. No formal education is used as the base category. For the employment status of the household head, four employment categories were identified using separate dummies: self employment, paid employment in the public sector, paid employment in the private sector, and unpaid labour (reference category). The gender of the household head was entered as a dummy with male being the base category. The number of children in household was generated by summing all household members aged less than 18 years.

\subsection{Data Sources}

The study used Labour Force Survey (LFS) 2005/06 data collected by Central Statistics Office (CSO) using the two-stage sampling design based on the 2001 Population and Housing Census. In the first stage, the Enumeration Areas (EAs) were sampled from the total 4,143 EAs delineated in the 2001 Population and Housing Census with probability proportional to measures of size. The second stage involved the sampling of households from the sampled EAs. Based on the two stage sampling method, CSO then computed appropriate weights to make the data to be representative at the national level.

\section{Multinomial Regression Results}

The results for the multinomial regression results for the determinants child labour and employment choice in Botswana are presented in table 5. 


\begin{tabular}{|c|c|c|c|c|c|c|c|c|c|}
\hline \multirow[t]{2}{*}{$\begin{array}{l}\text { Explanatory } \\
\text { Variables }\end{array}$} & \multicolumn{3}{|c|}{$\begin{array}{l}\text { Working and } \\
\text { schooling }\end{array}$} & \multicolumn{3}{|c|}{ Working and not schooling } & \multicolumn{3}{|c|}{$\begin{array}{l}\text { Not Working and } \\
\text { schooling }\end{array}$} \\
\hline & 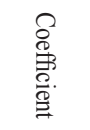 & N & $\vec{v}$ & $\begin{array}{l}8 \\
8 \\
\stackrel{9}{9} \\
\stackrel{0}{9} \\
\stackrel{9}{9}\end{array}$ & N & $\vec{v}$ & $\begin{array}{l}8 \\
\stackrel{8}{0} \\
\stackrel{9}{2} \\
\stackrel{0}{9}\end{array}$ & $\mathrm{~N}$ & $\vec{N}$ \\
\hline $\begin{array}{l}\text { Dummy for } \\
\text { female child } \\
\text { ( } 1=\text { female })\end{array}$ & -1.223 & -16.7 & 0.0000 & -0.843 & -8.5 & 0.0000 & -0.542 & -7.7 & 0.0000 \\
\hline $\begin{array}{l}\text { Dummy for } \\
\text { female headed } \\
\text { household } \\
\text { (1=female) }\end{array}$ & -0.514 & -6.8 & 0.0000 & 0.234 & 2.2 & 0.0250 & -0.120 & -1.7 & 0.0970 \\
\hline $\begin{array}{l}\text { Dummy for } \\
\text { both parent alive } \\
\text { (1=both parents } \\
\text { alive) }\end{array}$ & 0.774 & 7.4 & 0.0000 & 0.270 & 2.1 & 0.0350 & 0.802 & 8.4 & 0.0000 \\
\hline $\begin{array}{l}\text { Dummy for } \\
\text { single parent } \\
(1=\text { single parent } \\
\text { alive) }\end{array}$ & 1.206 & 10.1 & 0.0000 & -1.768 & -9.0 & 0.0000 & 0.903 & 8.0 & 0.0000 \\
\hline $\begin{array}{l}\text { Education level } \\
\text { of child, in years } \\
\text { of schooling }\end{array}$ & -0.023 & -2.3 & 0.0240 & 0.034 & 2.3 & 0.0220 & -0.196 & -20.1 & 0.0000 \\
\hline $\begin{array}{l}\text { Dummy } \\
\text { for primary } \\
\text { education level } \\
\text { of household } \\
\text { head (=1 if } \\
\text { primary) }\end{array}$ & -0.826 & -3.3 & 0.0010 & 1.958 & 8.0 & 0.0000 & -3.029 & -12.7 & 0.0000 \\
\hline $\begin{array}{l}\text { Dummy for } \\
\text { junior secondary } \\
\text { education level } \\
\text { of household } \\
\text { head (=1 } \\
\text { if junior } \\
\text { secondary) }\end{array}$ & 0.050 & 0.2 & 0.8410 & 1.934 & 7.1 & 0.0000 & -0.703 & -2.9 & 0.0040 \\
\hline $\begin{array}{l}\text { Dummy for } \\
\text { senior secondary } \\
\text { education level } \\
\text { of household } \\
\text { head (=1 } \\
\text { if senior } \\
\text { secondary) }\end{array}$ & -0.189 & -1.1 & 0.2920 & 1.794 & 7.2 & 0.0000 & -0.620 & -3.6 & 0.0000 \\
\hline Household size & 0.143 & 3.9 & 0.0000 & -0.407 & -8.5 & 0.0000 & 0.002 & 0.1 & 0.9640 \\
\hline $\begin{array}{l}\text { Household size } \\
\text { squared }\end{array}$ & -0.023 & -10.2 & 0.0000 & 0.021 & 7.1 & 0.0000 & -0.013 & -6.3 & 0.0000 \\
\hline $\begin{array}{l}\text { Number of } \\
\text { children in } \\
\text { household }\end{array}$ & 0.373 & 13.2 & 0.0000 & -0.249 & -5.7 & 0.0000 & 0.292 & 11.0 & 0.0000 \\
\hline Constant & 1.463 & 5.3 & 0.0000 & -16.262 & 1.3 & 0.2935 & 4.544 & 17.4 & 0.0000 \\
\hline
\end{tabular}

(Outcome Not working and not schooling is the comparison group) 


$\begin{array}{lr}\text { Number of obs }= & 37,623 \\ \text { LR chi2(33) }= & 8074.21 \\ \text { Prob }>\text { chi2 }= & 0.0000 \\ \text { Pseudo R2 }= & 0.1318\end{array}$

The dependent variable was a categorical variable which captured the selection of the individual into any of the four child labour and schooling states, with those not working and not schooling being the base category. The results suggest that the model is good with estimated parameters being jointly significantly different from zero (Prob $>$ chi $2=0.0000$ ). The significance of each of the parameter estimates is tested at least at the 10 percent significance level, with the focus being on the $P>Z$ statistic. If this statistic is less than 0.1 , then the parameter estimate is significantly different from zero at 10 per cent level holding other variables constant.

Relative to the reference category, the probability of children both working and schooling is negatively and significantly influenced by the gender of the child being female, being from a female headed household, education level of child, education level of the household head and household size. By implication children from female headed households are less likely to engage in child employment while at the same time schooling as compared to children from male headed households. One possible explanation to this scenario is that the women value the education of children more than the males which may be explained by the historical background of the Batswana (Chernichovsky, 1985). The men used to work in the mines in South Africa leaving the care of households under the women. While the girls were mainly at school (with the exception of those that dropped out due to pregnancy or early marriage), the boys were mainly engaged in cattle posts and this partly explains why women on average have higher levels of education than the men, hence were more likely to value the education of children than the men.

The higher the education level of the child, the lower will be the probability of engagement in child labour and schooling. The intuition of this result may be that children who have attained a relatively higher level of education are more likely to have a better understanding of the potential benefits from education and therefore less likely to engage both in labour market activities and schooling.

Primary education level of the household head has a negative and significant effect on the probability of child engagement in labour market activities and schooling. By implication household heads with some education level appreciate the value of children mainly concentrating on their schooling, hence minimize child involvement in labour market activities as well. What was puzzling though was the statistically insignificant effect of higher education levels of household heads.

The variables that captured the employment status of the householdheads (that is paid employment in either the private or public sectors and self-employment) were insignificant and therefore dropped from the model. However this was strange because empirical literature argues that employment generates income to the 
household which diminishes the need to engage children in labour market activities to supplement family earnings, which creates a conducive environment to keep children in school. Psacharopoulos and Arriagada (1987) in their study in Brazil also observed that parents' employment status had a positive and significant effect on the probability of children being enrolled in school.

The probability of child labour and schooling was positively and significantly influenced by household size, the number of children in the household, children having both parent alive, and children being from single parent households. The positive and significant effect of the number of children in the household on the probability of children being engaged in child labour and schooling may be explained by the poverty status of the household. Empirical literature argues that poor households tend to have high numbers of children and as such children are forced to engage in child labour to supplement family earnings (Psacharopoulos and Arriagada, 1987). In addition as the number of children increases, per capita schooling resources for each child decreases, hence forcing the children to participate in the labour market.

Relative to children who are orphans, those with both parents alive or one parent alive are more likely to be engaged in the labour market as well as schooling which is quite surprising. In seminar presentation of the preliminary results of this work, the participants raised that the very serious problem in Botswana is in the parents living together but not so much whether the parents are alive or not. According to them, you find several cases where the husband and the wife are living separately and children in most cases are left under the care of mothers which have serious implications for children's schooling and labour market participation. However the available labour force survey data 2005/06 did not capture this variable of parents living together and so could not be factored into the analysis.

\section{Summary of Results and Policy Implications}

Botswana policy on child labour is very clear: no child should be employed whatsoever while still at school and below the age of 14 (Republic of Botswana, 2002). Heavy penalties were prescribed for offences related to employment of children ranging from fine of P1,500 to 12 month imprisonments or both. However, it is the current reality in the country that children are engaged in child labour as well as schooling. This raised fundamental policy issues in the country. The main driver of child labour in the Botswana is socioeconomic characteristic of households where these children come from, in particular poverty status of these households. These socioeconomic factors may point to increasing levels of poverty or increasing inequality in income distribution. This is consistent with the Household Income and Expenditure Survey of 2002/2003 which observes that the Gini income inequality coefficient rose from 0.537 in 1993/94 to 0.573 in 2002/03 (CSO, 2004). Also, our results show that children are mainly engaged in work to assist parents or to get money to support themselves which may be a reflection of inadequate resources 
from parents to support the children. The policy implication is that reduction of child labour market participation depends strongly on economic growth and development, particularly the reduction of poverty and income inequality.

\section{References}

Austen, S. (2005) "The Determinants of Labour Force Participation for Older Australian Women: A Statistical Analysis of the Negotiating the Life Course Survey Data” Women in Social \& Economic Research Working Paper No 46, http://www.cbs.curtin.edu.au/wiser (September)

BARROS, Ricardo \& SANTOS, (1991) Eleonora. Consequências de Longo Prazo do Trabalho Precoce. IPEA - Relatório Interno no 6. Rio de Janeiro, july.

BARROS, Ricardo., MENDONÇA, Rosane. \& VELAZCO, (1994) Tatiana. Is Poverty the Main Cause of Child Work in Urban Brazil?. IPEA - Texto para Discussão no 351. Rio de Janeiro, oct.

Basu, Kaushik (1999) Child Labor: Cause, Consequence, and Cure, with Remarks on International Labor Standards, Journal of Economic Literature, Vol. 37, no 3, September.

Basu, Kaushik and Ray Rajan (2002) The Collective Model of the Household and an Unexpected Implication of Child Labor. The World Bank's Policy Research Working Paper 2813.

Bhalotra, S. and C. Heady, (2001), "Child Activities in South Asia and Sub-Saharan Africa: A Comparative Analysis", Published in P. Lawrence and C. Thirtle, eds., Africa and Asia in Comparative Development, (London: Macmillan), (September)

Bhalotra, Sonia and Heady Christopher (2003) Child Farm Labour: The Wealth Paradox. Discussion Paper No 03/533, Department of Economics, University of Bristol.

Bock J. (2002), "Evolutionary demography and intrahousehold time allocation: school attendance and child labor among the Okavango Delta Peoples of Botswana", American Journal of Human Biology, 14(2):206-21. (March-April).

Brown, D. K.,Alan V. Deardorff and R. M. Stern, (2002), “The Determinants of Child Labour: Theory and Evidence" Research Seminar in International Economics, School of Public Policy, The University of Michigan, Discussion Paper No. 486 (Michigan)

Chaudhri, D.P., A.L. Nagar, T. Rahman and E.J. Wilson (1999) (Determinants of Child Labour in Indian States: Some Empirical Explorations (1961-1991)" Working Paper 99-9, Department of Economics, University of Wollongong. 
Chernichovsky, D. (1985). Socioeconomic and Demographic Aspects of School Enrollment and Attendance in Rural Botswana. Economic Development and Cultural Change 32(1), 319-332.

Dayioglu, Meltem and Assa, Ragui (2002) The Determinants of Child Labour in Urba Turkey. ERF Working Paper Series No. 0302.

de Carvalho Filho, I.E. (2008), "Household Income As A Determinant of Child Labor and School Enrollment in Brazil: Evidence From A Social Security Reform" IMF Working Paper, IMF, Washington, D.C. USA.

Edmonds, Eric V. (2006), "A Review of Alessandro Cigno and Furio Rosati's The Economics of Child Labour" (Oxford University Press, 2005), The Journal of Economic Literature, (December).

Emerson, Patrick and Souza Andre (2005) Bargaining Over Sons and Daughters: Child Labor, School Attendance and Intra-household Gender Bias in Brazil. Working Paper series No. 0213, Vanderbilt University.

Grootaert, C. and Patrinos, H. A. (Eds.). (1999) The policy analysis of child labor: A comparative study. New York, NY: St Martin's Press.

Grootaert, C. and R. Kanbur (1995). "Child Labor: A Review", Policy Research Working Paper No. 1454, Washington, DC: The World Bank.

Grootaert, Christiaan (1998), Child Labor in Côte d'Ivoire: Incidence and Determinants", Social Development Department, World Bank, Washington, D.C.

ILO (1996), Child Labour: Targetting the Intolerable, ILO, Geneva.

ILO (2006), The end of child labor: Within reach. ILO, Geneva.

Jensen, P. and H. S. Nielsen. (1997). "Child Labor or School Attendance? Evidence from Zambia", Journal of Population Economics, Vol. 10.

Kambhampati, Uma and Rajan, Raji. (2004) Does Child Work Decrease with Parental Income? The Luxury Axiom Revisited in India. mimeo: University of Reading

Khanam, R. (2004), “Child Labour in Bangladesh: Determinants and Effects" http:// mpra.ub.uni-muenchen.de/6990/2/Final_Manuscript_IJSE_pdf

LEME, Maria Carolina, WAJNMAN, Simone. A alocação do tempo dos adolescentes brasileiros entre o trabalho e a escola. In: XII Encontro Nacional de Estudos Populacionais, Anais, ABEP, Caxambú, 2000 (Available in CD-ROM).

Lloyd, C. B. (1994). "Investing in the Next Generation: The Implications of High Fertility at the Level of the Family." New York Population Council, Research Division Working Paper No. 63.

Muniz, J. O. (2001), “An Empirical Approach for Child Labour in Brazil”, A text 
of the paper presented at the IUSSP XXIV General Population Conference, Salvador, Brazil (August).

Patrinos, H.A. and G. Psacharopoulos (1997), "Family Size, Schooling and Child Labor in Peru - An Empirical Analysis." Journal of Population Economics, vol. 10, no. 4, pp. 387-405.

Psacharopoulos, G. (1997), "Child Labor versus Educational Attainment: Some Evidence from Latin America." Journal of Population Economics, vol. 10, no. 4, pp. 377-386.

Psacharopoulos, G. and Arriagada, A.M. (1987), "School Participation, Grade Attainment and Literacy in Brazil: A 1980 Census Analysis", Discussion Paper No. EDT86, http://siteresources.worldbank.org/BRAZILINPOREXTN/ Resources/3817166--1185895645304/4044168--1186326902607/38pub_br59. pdf

Ray, R. (2000) Analysis of Child Labour in Peru and Pakistan: A Comparative Study. Journal of Population Economics, Vol. 13, No 1, pp. 3-19.

UNICEF, (2007), “Child Labour, Education and Policy Options” Division of Policy and Planning, Working Papers, NY, USA.

ZYLBERSTAJN, Hélio., et al. (1985) A mulher e o menor na força de trabalho. São Paulo: Nobel, 1985. 